\title{
Matematické stanovení batymetrie vodního toku - software Bathy_supp
}

\section{BUREŠ LUDĚK, PETRA SYCHOVÁ, LENKA PAVLÍČKOVÁ, ŠTĚPÁN MARVAL, FILIP URBAN, RADEK ROUB}

Klíčová slova: letecké laserové skenování - hydrodynamický model - batymetrie - vodní tok - digitální model terénu - povodně

\section{SOUHRN}

Topografické údaje hrají klíčovou roli v otázce presného hydrodynamického modelování povodňových událostí. Často je vyžadován přesný digitální model terénu (DMT), který obsahuje popis říční batymetrie. DMT může být získán z různých zdrojů dat, jako jsou pozemní měření nebo metody dálkového průzkumu země. Pořízení pozemních, zejména geodetických, dat bývá často finančně nákladné a časově náročné. Další alternativou získání dat DMT jsou satelitní zdroje, ty však zpravidla nedosahují přesností, které jsou vhodné pro korektní hydrodynamické modelování. Jako nejvíce vhodná se proto jeví data pořizená technologií leteckého laserového skenování (LLS).

Pro sběr dat LLS se v ČR využívá snímání infračerveným laserovým paprskem. Omezením ve využití této technologie pro hydrodynamické modelování je fakt, že infračervený laserový paprsek je pohlcován vodní hladinou. V praxi to znamená, že nelze získat výškopisnou informaci o morfologii terénu pod vodní hladinou. Při tvorbě DMT z dat LLS tak dochází k vytvoření modelu, který zanedbává průtočnou plochu zaměřovaného koryta vodního toku.

$\checkmark$ tomto príspěvku jsou prezentovány výsledky z vyvíjeného softwaru Bathy_supp, který stanovuje batymetrii přirozeného říčního koryta. Batymetrie je stanovena pomocí analytických křivek, které popisují průběh přícných profilù. Následně je provedena prostorová interpolace mezi odhadnutými profily, jejímž výsledkem je batymetrická bodová sít. Vytvořenou batymetrickou bodovou sít Ize spojit např. s daty LLS a vytvořit tak DMT vhodný pro hydrodynamické modelování. V príspěvku je prezentován praktický př́iklad testování softwaru na pilotní lokalitě. Dosažené výsledky ukazují, že výsledky softwaru Bathy_supp výrazně zlepšují model terénu vytvořený z dat LLS.

\section{ÚVOD}

Klíčovou znalostí pro hydrodynamické modelování povodní je morfologie terénu. Přesnost a využitelnost hydrodynamických modelů závisí na charakteru, dostupnosti a přesnosti zdrojových topografických dat, ze kterých je generován výsledný DMT [1].

Relevantní výškopisné údaje o morfologii koryt vodních toků a přilehlého inundačního území je možné získat rưznými, navzájem často kombinovatelnými metodami. Jednou z metod získání zdrojových dat pro DMT je měěení pomocí družicových polohových systémů. Tato data však nejsou, díky svému rozlišení, pro hydrodynamické modelování dostatečně přesná. Naopak velmi přesnou metodou získání dat pro DMT je pozemní geodetické měření, tato metoda je nicméně časově i finančně velmi náročná. Třetí, nejmodernější, metoda spočívá ve využití technologie LLS, která má široké uplatnění v celé řadě oborů. Běžně se využívá při pořizování prostorových geografických dat pro potřeby v geodézii, ve stavebnictví, v lesnictví, v archeologii atp. Významnou možností využití LLS je i oblast vodního hospodářství, prríkladem je zpřesňování polohy os vodních toků a vodních ploch [2] nebo tvorba map povodňových rizik [3].

Metoda LLS [4] využívá technologii LiDARu (Light Detection and Ranging). Princip této technologie spočívá v měření doby návratu vyzařovaného laserového paprsku. Analýzou této doby je pak určena vzdálenost měřcí jednotky (na palubě letadla) od snímaného objektu (povrchu Země), resp. nadmořská výška mapovaného zemského povrchu. Výhodou LLS je jednak rychlost získání dat, dále vysoká přesnost a vysoké prostorové rozlišení vznikajícího DMT. Skenery použivané k celoplošnému mapování využívají laser o vinové délce blízké infračervenému spektru, přičemž voda toto záření zcela pohlcuje [5]. To sice umožňuje přesnou identifikaci hranice vodních ploch, nicméně informaci o batymetrii dna nepodává. Proto byla vyvinuta duální forma LiDARu (DiAL - Differential Absorption Lidar), která kombinuje dva laserové paprsky vyzařované v různých vlnových délkách, v infračerveném spektru (1 064 nm) pro mapování topografie terénu a v zeleném (zeleno-modrém) spektru (532 nm), které proniká pod vodní hladinu [6, 7]. Tento specifický typ LLS, známý rovněž pod označením letecké batymetrické laserové skenování (LBLS) nebo $v$ anglickém originále Airborne Lidar Bathymetry (ALB), se používá predevším v mělkých příbřežních mořských vodách [8].

Stále však přetrvávají jistá omezení, míra proniknutí zeleného paprsku vodním sloupcem závisí na průhlednosti, resp. zákalu a proudění vody [9, 10]. Někteří autoři [6-8] deklarují, v závislosti na vnějších podmínkách (průhlednost vody, zákal, .. .), že reálná batymetrická data lze získávat až do hloubky 50 m pod vodní hladinu s horizontální přesností $\pm 2,5$ m a s vertikální přesností $\pm 0,25$ m [7]. Guenther a kol. [8] navíc doporučuje věnovat maximální pozornost správnému načasování snímkování a případně mapování opakovat. V podmínkách ČR byly, parametricky obdobným vybavením, testovány vybrané vodní nádrže a 6 km dlouhý úsek vodního toku. Relevantní výsledky byly ovšem dosaženy pouze do hloubky 1,5-2 m pod vodní hladinou v prípadě vodní nádrže a do hloubky 0,8 m $\checkmark$ prípadě vodního toku [11].

Důsledkem nejistoty získání relevantních výsledků LBLS mohou být nespolehlivá zdrojová data. Konkrétně může dojít k zanedbání hloubky a tvaru koryta, což je zásadní problém pro hydrodynamické modelování ríčních tokủ a správné posouzení ekologických a geomorfologických vlastností vodních toků [12].

Další možností tvorby vysoce přesného a batymetricky korektního DMT je kombinace dat LLS s daty pozemního měření charakterizující tvar koryta vodních toků. Dodatečným zdrojem batymetrických dat může být geodetické zaměření vodního toku nebo zaměěení s využitím SONARu (SOund Navigation And Ranging), tedy zařízením využívající akustických vin jednak k navigaci a zaměřování objektů pod vodou, ale také k měření hloubek [13]. Specifickým prístrojem pro získání batymetrických dat je prístroj ADCP (Acoustic Dopler Current Profiler) využívající Dopplerova jevu. Primárně je určen pro měření 
průtoku v otevřených korytech řek, jeho sekundárním využitím je pak batymetrické mapování [13]. Všechny tyto metody jsou však časově i finančně náročné.

Nabízí se otázka alternativního zjištění tvaru příčného profilu vodního toku, resp. velikosti průtočné plochy, tedy hlavních vstupních dat pro hydrodynamické modely. Existují různé metody doplnění chybějících dat charakterizující tvar koryt vodních toků v jejich přirozeném tvaru.

Caletka [14] popisuje metodu lineární extrapolace chybějicích dat z původních rastrů na základě sklonu břehů v rámci přičných profilů, kde je schematizace prováděna na základě volby vhodného geometrického obrazce, který by ideálně vystihoval řešený príčný profil. Výsledky využití této metody zatím ukazují mírné nadhodnocování minimální úrovně dna koryta vodního toku.

Další možností využití softwarových metod pro doplnění chybějících batymetrických dat je software CroSolver [15, 16]. Ten nahrazuje říční batymetrii korytem lichoběžníkového nebo obdélníkového průřezu. Model koryta vodního toku je následně spojen s daty LLS a vzniká tak zpřesněný DMT.

Inovativním přístupem ke stanovení reálné profilace vodního toku je vývoj softwarového prostředku Bathy_supp. Software využívá matematického stanovení tvaru přičných profilů na základě jejich rozmístění v modelované oblasti. Následně dopočíává kompletní batymetrii modelovaného úseku vodního toku. Takto získaná batymetrická data jsou posléze spolu se vstupními topografickými daty (TOPO) využita pro tvorbu celistvého DMT.

\section{PROGRAM BATHY_SUPP}

Program Bathy_supp je vytvořen jako samostatně spustitelný program v programovacím jazyku C++ a je určen pro stanovení batymetrie vodního toku. Koryto vodního toku může být určeno v programu na základě zobrazení dat TOPO, nebo jako seznam souřadnic příčných profilů, definujících geometrii budoucího koryta vodního toku. Výstupem je seznam souřadnic definujících (výškově i polohově) novou batymetrii koryta $v$ textovém formátu. Tento výstup může být nadále použit $v$ geografických informačních systémech (GIS) k samotné syntéze dat z programu Bathy_supp a dat TOPO pro tvorbu celistvých DMT.

\section{Vstupní data}

Jak již bylo řečeno, základními vstupními údaji jsou data TOPO, v našem př́padě získaná metodou LLS. Tento vstup je ve formě seznamu diskrétních bodů o souřadnicích XYZ. Tato data musí být v textovém formátu s koncovkou "*.txt" nebo " ${ }^{*} \cdot x y z$ ", shodně řazenými v pořadí XYZ. Dalšími vstupními daty jsou informace o průtoku $v$ říčním korytě $v$ době pořízení dat TOPO a drsnostní charakteristika koryta.

\section{Popis programu}

Batymetrický výpočet je proveden na základě virtuálních prríčných profilů, jejichž rozmístění definuje uživatel v rámci modelovaného úseku řeky. $V$ těchto profilech je z dat TOPO určena nadmořská výška hladiny vody, na jejímž základě jsou následně odvozeny jednotlivé profily, definované souřadnicemi XYZ. Podle zvolené schematizace jsou pak mezi profily interpolovány souřadnice nových batymetrických bodů. Tímto postupem vzniká bodová sít, ze které je možné za použití běžných interpolačních technik vytvořit 3D batymetrický model koryta vodního toku.

\section{GEOMETRIE VODNÍHO TOKU}

Prvním krokem po spuštění programu je nahrání dat TOPO. Na základě zobrazení dat TOPO je možné v grafickém okně programu zvolit umístění modelovaných příčných profilů. Poloha těchto profilů definuje geometrii modelované části vodního toku, proto je nutné pečlivě zvažovat jejich rozmístění v modelovaném prostoru. Profily musí být definovány $v$ po sobě jdoucím pořadí, a to od nejvýše umístěného profilu. Délka profilů definuje šiřku koryta, pro níz bude batymetrický výpočet proveden. Rozestup profilů musí být volen s ohledem na výběr schematizačního algoritmu (viz kap. Meziprofilová interpolace). Počet zadávaných profilů je volen uživatelem. Alternativou je možnost nahrát umístění profilů formou seznamu jejich definičních bodů.

\section{ZAHLOUBENÍ MODELOVANÝCH PŘÍČNÝCH PROFILŮ}

Pro modelované př́ičné profily je odečtena z dat TOPO nadmořská výška hladiny $v$ místě profilu. Toho je docíleno tak, že v okolí koncových bodů každého profilu je programem vyhledán bod s nejnižší nadmořskou výškou. Tato nadmořská výška je vybrána jako výška hladiny vody v době pořizení dat TOPO. Po určení nadmořské výšky hladin v profilech program automaticky zkontroluje celkový podélný profil hladiny toku, prípadně nadmořské výšky hladin v profilech automaticky upraví.

Zahloubení koryta je provedeno na základě analytické křivky. Jedná se o dvou-parametrickou křivku, jejiž prohnutí (schopnost popsat průběh prríčného profilu) záleží na velikosti jejích parametrů (obr. 1). Parametry jsou určeny regresní rovnicí na základě náklonu profilů a břehových vzdáleností po sobě jdoucích modelovaných příčných profilů. Parametry regresní rovnice je možné v programu upravovat a tím průběh příčného profilu ovlivňovat. Program také umožňuje manuální korekci regresních parametrů na základě uživatelem vloženého reálného vzorového profilu. Zahloubení je provedeno tak, aby bylo dosaženo ekvivalentní průtočné plochy v modelovaném profilu. Ekvivalentní průtočná plocha je určena výpočtem za využití Chézyho rovnice. Pro tento výpočet uživatel zadává průtok v modelovaném říčním úseku a Manningův součinitel drsnosti ze dne pořizení dat TOPO. Podélný sklon je automaticky určován ze vzdálenosti a rozdílů nadmořských výšek hladin v po sobě jdoucích profilech. Počet bodů, z nichž se budou modelované profily skládat, definuje uživatel.

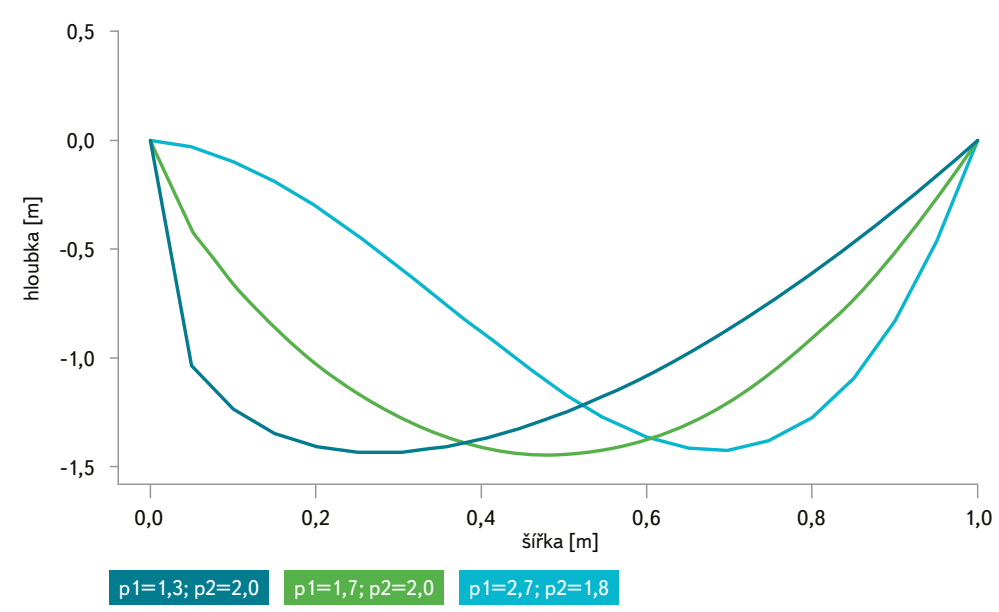

Obr. 1. Príklady prohnutí analytické křivky

Fig. 1. Examples of deflection of the analytical curve

\section{MEZIPROFILOVÁ INTERPOLACE}

Pro vytvoření batymetrie vodního toku je nutné provést prostorovou interpolaci mezi modelovanými príčnými profily. Celková batymetrie vodního toku je v programu schematizována bodovou 3D sítí. Hustota této sítě závisí na počtu bodů v modelovaných príčných profilech a počtu bodů mezi profily. Oba parametry určuje uživatel. Pro vytvoření 3D sítě z 3D modelovaných profilů Ize využít celkem tři algoritmy pro tvorbu sítí (obr. 2). 
První algoritmus (SA1) [17] používá pro podélnou (prostorovou) interpolaci mezi profily lineární interpolační algoritmus. Ten provádí interpolaci mezi odpovídajícími si body v po sobě jdoucích profilech. To znamená, že nově vzniklé body leží na prímce mezi výchozími body. Pro interpolaci nadmořských výšek je použita také lineární interpolace.

Druhý algoritmus (SA2) [18] modelovaný profil nejdřive převzorkuje. Touto úpravou dojde ke změně rozestupu bodů tak, aby na obě strany od nejhlubšího místa v profilu ležel stejný počet bodů. Pưvodní tvar profilu však zůstává zachován. Díky převzorkování je respektována spojnice míst s nejnižší hloubkou $\vee$ profilech. To má za následek reálnějši schematizaci průběhu hloubek mezi profily. Poté je opět využito lineární interpolace pro dopočet bodů mezi profily a jejich nadmořských výšek.

Třetí algoritmus (SA3) [19] využívá také převzorkování modelovaného profilu a navíc pro prostorové rozmístění nových bodů mezi profily využívá kubické hermitovské interpolace (CHS). Nové body tak nevznikají na přímkové spojnici, ale jsou interpolovány po obloukové křivce. To zajištuje věrohodnější popis koryta mezi modelovanými profily zejména v ríčních obloucích. Pro interpolaci nadmořských výšek je opět použita lineární interpolace.

Lineární interpolace (SA1, SA2)

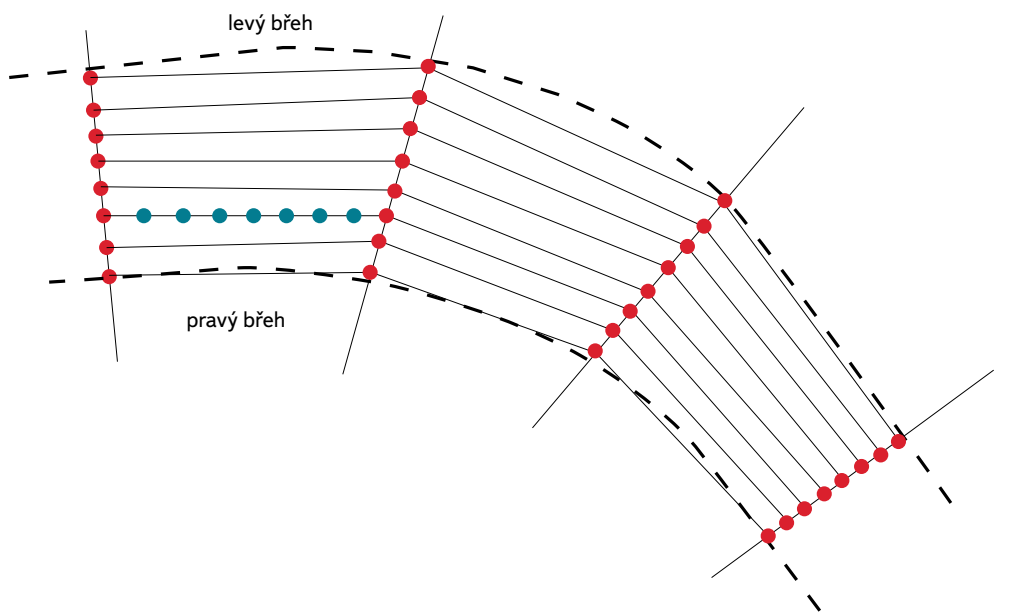

Kubická Hermitovská interpolace (SA3)

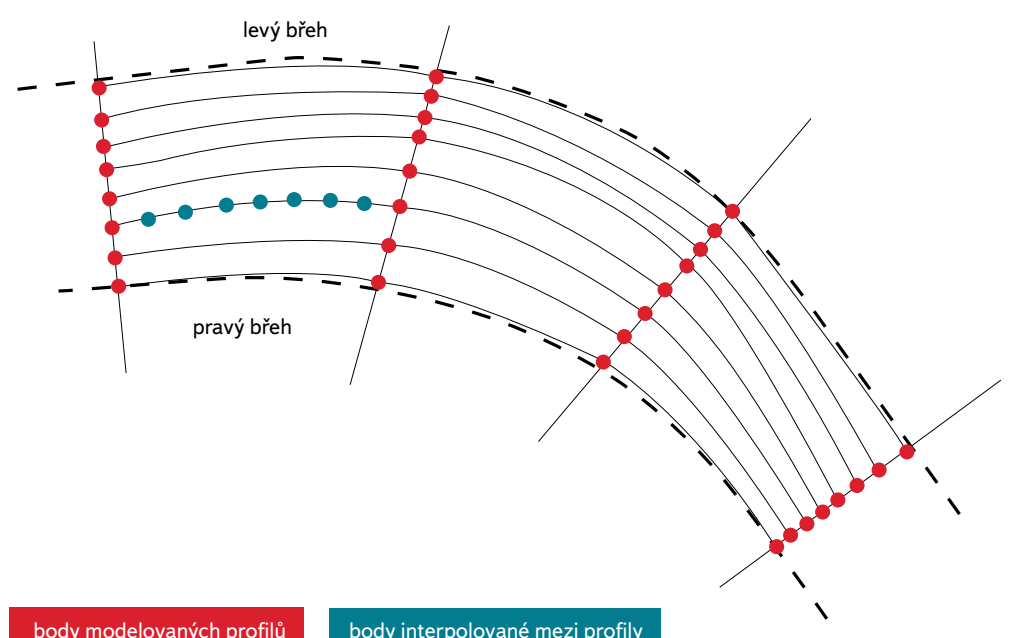

Obr. 2. Interpolace mezi profily

Fig. 2. Interpolation between cross-sections

\section{APLIKACE SOFTWARU BATHY_SUPP}

\section{Pilotní území}

Jako pilotní území byl vybrán úsek řeky Otavy v Písku (obr. 3), především z důvodu dostupnosti topografických a hydrologických dat (ve studovaném úseku se nachází měrný profil č. 127). Vybraný úsek je 1,65 km dlouhý a je lokalizován v úseku mezi 22,83-24,48 řičního kilometru (ř. km). Šiřrka toku ve studovaném území se pohybuje mezi 25-35 m. Průměrná hloubka toku je 0,94 m. Průměrný roční průtok je $23,4 \mathrm{~m}^{3} . \mathrm{s}^{-1}$. Průměrná nadmořská výška hladiny se pohybuje okolo 354,84 m n. m. Přehled povodňových událostí v tomto říčním úseku je uveden v tabulce 1. Návrhové průtoky $\left(\mathrm{Q}_{N}\right)$ pro tento úsek jsou uvedeny v tabulce 2.

Tabulka 1. Povodñové události ve studovaném úseku

Table 1. Flood events in study river reach

\begin{tabular}{lll} 
Datum & Poloha hladiny $[\mathrm{m} \mathbf{n} . \mathbf{m}]$. & Průtok $\left[\mathrm{m}^{3} \cdot \mathbf{s}^{-1}\right]$ \\
\hline 9.7. 1954 & 359,83 & 800 \\
\hline 11. 6. 1965 & 357,28 & 290 \\
\hline 23. 8. 1977 & 357,4 & 308 \\
\hline 23. 7. 1980 & 357,28 & 338 \\
\hline 20. 7. 1981 & 358,18 & 500 \\
\hline 3. 8. 1991 & 357,46 & 247 \\
\hline 21. 12. 1993 & 358,98 & 520 \\
\hline 13. 8. 2002 & 362,7 & 1175 \\
\hline
\end{tabular}

Tabulka 2. Návrhové průtoky $Q_{N}$

Table 2. N-yearflow discharges

\begin{tabular}{llllll} 
Doba opakování $\mathbf{Q}_{\mathrm{N}}$ & $\mathrm{Q}_{1}$ & $\mathrm{Q}_{5}$ & $\mathrm{Q}_{10}$ & $\mathrm{Q}_{50}$ & $\mathrm{Q}_{100}$ \\
\hline Průtok $\left[\mathrm{m}^{3}\right.$.s $\left.^{-1}\right]$ & 146 & 300 & 394 & 680 & 837
\end{tabular}

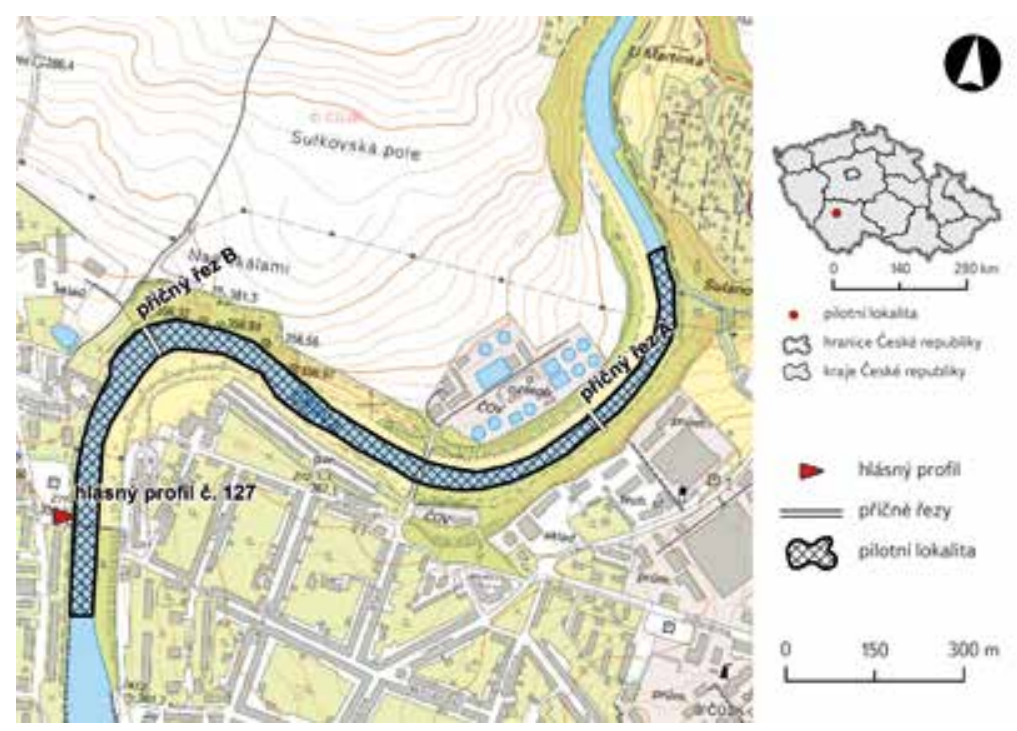

Obr. 3. Zájmové území

Fig. 3. The area of interest 


\section{Vstupní data}

Data TOPO pochází z digitálního modelu reliéfu 5. generace (DMR 5G), který představuje zobrazení přirozeného nebo lidskou činností upraveného zemského povrchu [20]. Data DMR 5G jsou standardně dodávána v požadovaném formátu s koncovkou "*.xyz". Data byla pořízena dne 18. 4. 2011 ve 13:00 hod. Průtok v řece Otavě v tuto dobu byl $36,8 \mathrm{~m}^{3} \cdot \mathrm{s}^{-1}$. Hodnota Manningova drsnostního součinitele $\left(0,025 \mathrm{~s} \cdot \mathrm{m}^{-1 / 3}\right)$ byla zjištěna kalibrací hydrodynamického modelu se zaměřenou topografí.

\section{Tvorba DMT pro hydrodynamické modelování}

Na základě vstupních dat byl programem Bathy_supp proveden výpočet tří batymetrických sítí (SA1-SA3), které byly $\vee$ prostředí ArcGIS spojeny $s$ daty DMR 5G. Následně byly vytvořeny celistvé modely terénu, kde batymetrické sítě popisují prostor v korytě reky a DMR 5G definuje její široké okolí. Celkově bylo vytvořeno pět modelů terénu (viz obr. 4). Model ADCP, který byl vytvoren syntézou reálného zaměření koryta toku pomocí př́stroje RiverSurveyor M9 a dat DMR 5G, byl s ohledem na svou přesnost zvolen jako referenční. Model $5 G$ byl vytvořen pouze na základě dat DMR 5 G a neobsahoval žádné dodatečné informace o batymetrii koryta. Modely S1, S2 a S3 byly vytvořeny na základě syntézy príslušné batymetrické sítě (SA1, SA2 a SA3) s daty DMR 5G. Odhad prríčných profilů pro tvorbu batymetrických sítí SA1-SA3 byl totožný.

\section{Hydrodynamické modelování}

Pro hodnocení DMT z hlediska hydrodynamického modelování byl použit 1D model HEC-RAS, který byl použit v mnoha studiích hodnotících vliv různých zdrojů topografických dat na stanovení inundačních území [5, 21-24].

Hydrodynamické simulace provedené $v$ této studii se liší pouze topografickým zdrojem dat (5G, S1, S2, S3). Na sestavení ŕíční geometrie modelů bylo použito 24 príčných profilư. Manningův koeficient pro koryto řeky byl nastaven na 0,025 s.m $\mathrm{m}^{-1 / 3}$. Zvolené hodnoty Manningova koeficientu byly zjištěny kalibrací modelu na průtok blízký hodnotě $Q_{100}$. Jednalo se o průtok z 9. 7. 1954, jehož hodnota byla $800 \mathrm{~m}^{3} \cdot \mathrm{s}^{-1}$ (tabulka 1). N-leté návrhové průtoky $\left(\mathrm{Q}_{5^{\prime}} \mathrm{Q}_{50}\right.$ a $\left.\mathrm{Q}_{100}\right)$ byly použity jako horní okrajové podmínky. Kritická hloubka byla použita jako dolní okrajová podmínka. $V$ této studii byly všechny simulace vypočteny $v$ režimu ustáleného nerovnoměrného proudění $[25,26]$.

Výsledky vypočtené hydrodynamickým modelem byly následně zpracovány v programu ArcGIS za pomocí extenze HEC-GeoRAS, odkud byly exportovány hodnoty pro porovnání polohy hladiny (viz kap. Porovnání polohy hladiny) a velikosti inundační oblasti (viz kap. Porovnání velikosti inundační oblasti) [27].

\section{Vyhodnocení kvality DMT}

Kvalita výsledných DMT byla hodnocena formou detekce vertikálních rozdílů mezi testovanými a referenčním DMT. Jako referenční DMT byl zvolen ADCP z důvodu garance přesnosti jeho zdrojových dat. Pro hodnocení byly použity dvě metody výsledných DMT, jednou z nich bylo porovnání př́íných průřezů, druhou pak porovnání podélného profilu dna v ose toku. Pro porovnání přičných prưrezů bylo zvoleno 29 srovnávacích řezů, které byly náhodně rozmístěny $\vee$ modelované oblasti. Umístění těchto řezů bylo identické pro všechny hodnocené DMT. Střední kvadratická chyba (RMSE) a střední absolutní chyba (MAE) byly použity při hodnocení kvality DMT. Rovnice pro tato kritéria hodnocení jsou následující:

$$
\begin{aligned}
& \text { RMSE }=\sqrt{\frac{1}{N} \sum_{i=1}^{N}\left(\text { Elev }_{D M T}-\text { Elev }_{\text {REF }}\right)^{2}} \\
& M A E=\frac{1}{N} \sum_{i=1}^{N} \mid \text { Elev }_{D M T}-\text { Elev }_{\text {REF }} \mid
\end{aligned}
$$

kde Elev $_{\text {DMT }}$ je hodnota nadmořské výšky (m) odvozená z modelů 5G, S1, S2 a S3,

Elev $_{\text {REF }} \quad$ odpovídající referenční hodnota odvozená z modelu ADCP, N počet bodů definujících daný prưřez nebo osu toku.

\section{Vyhodnocení vlivu vstupních dat DMT při hydrodynamickém modelování}

Za účelem vyhodnocení vlivu dat DMT byla zkoumána rozloha inundační oblasti (IA) a nadmořské výšky hladin (WSE).

Použité hodnotící kritérium rozsahu inundační oblasti (IA):

$$
I A_{\text {dif }}=\frac{|| A_{D E M}-\left|A_{R E F}\right|}{I A_{R E F}} \cdot 100
$$

kde $\quad \mathrm{A}_{\mathrm{dif}}$ je rozdíl v rozsahu inundačních ploch v procentech,

IA $A_{D E M} \quad$ inundační plocha $\left(\mathrm{km}^{2}\right)$ produkovaná výstupními DMT,

$\mathrm{IA}_{\mathrm{REF}} \quad$ referenční (ADCP) inundační plocha $\left(\mathrm{km}^{2}\right)$.

IA a WSE byly hodnoceny pro N-leté průtoky $Q_{5^{\prime}} Q_{50}$ a $Q_{100}$. Pro toto hodnocení byl použit stejný prístup, jako je popsán $v$ kapitole Hydrodynamické modelování. Model ADCP byl opět zvolen jako zdroj referenčních údajů. Chyba WSE byla hodnocena pomocí rovnic 1 a 2 .

\section{VÝSLEDKY}

Program Bathy_supp na základě uživatelem definované geometrie vodního toku nejprve odhaduje prríčné profily a z nich je následně tvořena batymetrická sít. Ta je následně spojena s daty TOPO a je vytvořen výsledný DMT.

\section{Shoda v príčných profilech}

Vizuální porovnání prưřezů odvozených z hodnocených DMT je uvedeno na obr. 4. Část A ukazuje přičný řez terénem v rovném úseku řeky. Modely S1-S3 zde vykazuji podobné výsledky blízké referenčnímu modelu ADCP. Model $5 G$ vykazuje zásadní odchýlení. V části B je vyobrazen příčný řez říčním obloukem. Modely S1-S3 vykazují tvarovou podobnost, ale modely S1 a S2 jsou vychýleny mimo osu toku. Model $5 \mathrm{G}$ opět vykazuje zanedbání velké části koryta toku.

Obrázek 5 popisuje rozptyl $\vee$ hodnotách RMSE a MAE dosažených pro všechny srovnávací průřezy. Z výsledků vyplývá, že chyby modelů S1, S2 a S3 jsou srovnatelné. Model $5 G$ se od ostatních modelů opět výrazně liší. Jak je patrné z tabulky 3, celková hodnota RMSE modelu 5G byla 0,96 m. Pro S1, S2 a S3 to bylo 0,44 m, 0,43 m a 0,34 m. Celková hodnota MAE modelu $5 \mathrm{G}$ byla 0,68 m, zatímco hodnoty S1, S2 a S3 byly 0,25 m, 0,25 m a 0,2 m. Z výsledků je patrné, že nejmenších chyb dosahoval model S3. 


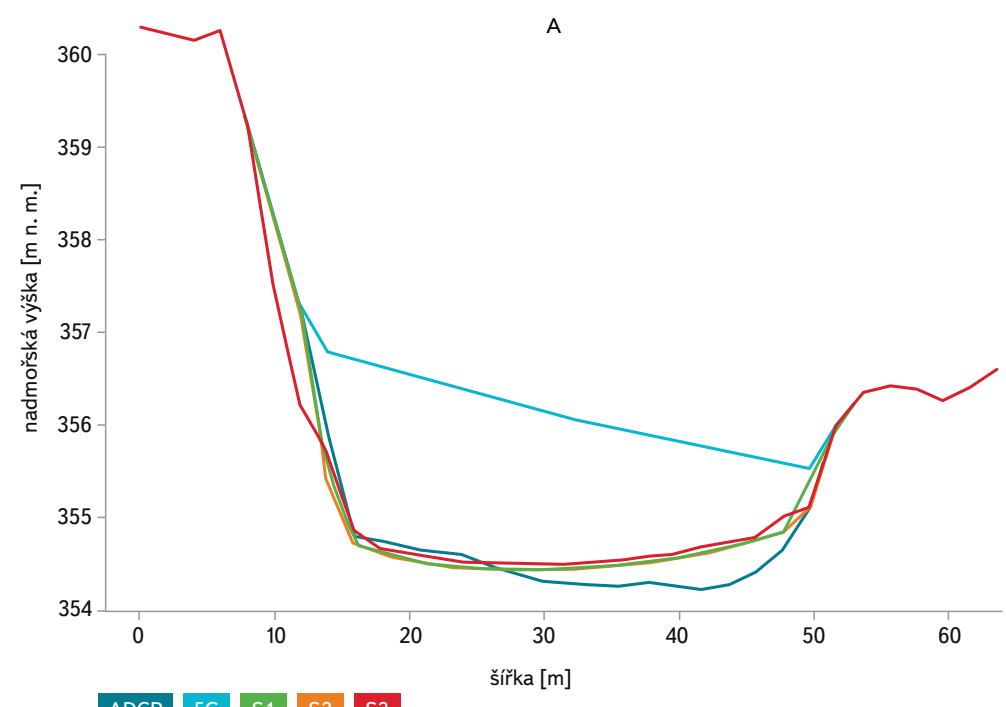

\begin{tabular}{ll|l|l|l} 
ADCP & $5 \mathrm{G}$ & $\mathrm{S} 1$ & $\mathrm{~S} 2$ & $\mathrm{~S} 3$
\end{tabular}

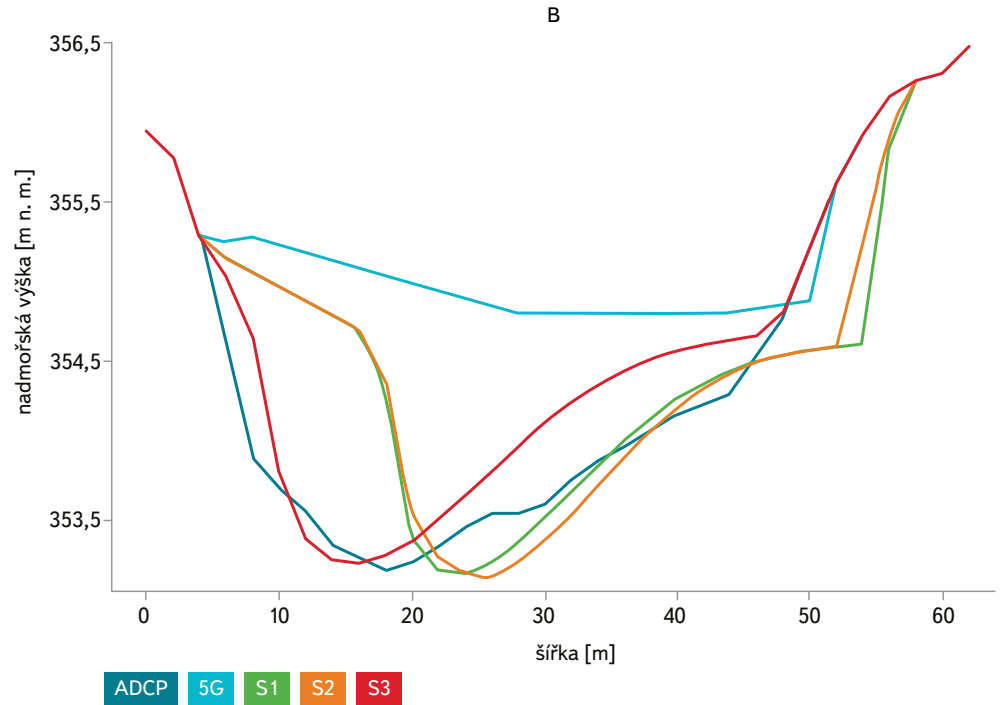

Obr. 4. Příčné řezy terénem; část A - řez v rovném úseku řeky; část B - řez v řičním oblouku

Fig. 4. Cross-sectional cuts; part A, cut in the straight section of the river; part B, cut in the river arc
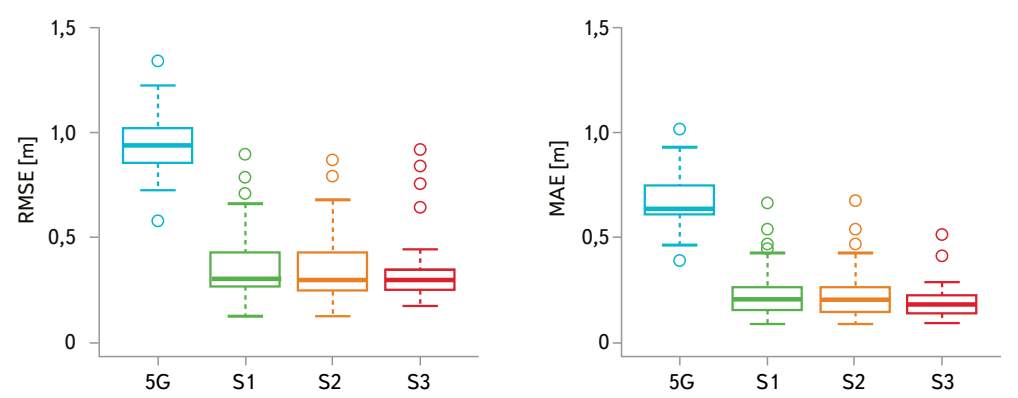

Obr. 5. Rozptyl hodnot střední kvadratické chyby (RMSE) a střední absolutní chyby (MAE) při porovnávání průřezů

Fig. 5. Variance of root mean square error (RMSE) and mean absolute error (MAE) values when comparing cross-sections
Tabulka 3. Hodnoty středních kvadratických chyb (RMSE) a stréednich absolutních chyb (MAE) pro porovnávané modely DMT (srovnáni prưrezů)

Table 3. Root mean square error (RMSE) and mean absolute error (MAE) values for the compared DEMs (cross-sectional comparison)

\begin{tabular}{lllll} 
& 5G & S1 & S2 & S3 \\
\hline RMSE $(m)$ & 0,96 & 0,44 & 0,43 & 0,34 \\
\hline MAE $(m)$ & 0,68 & 0,25 & 0,25 & 0,2
\end{tabular}

\section{Hloubka dna v ose koryta}

Vizuální srovnání rezů vedených osou vodního toku (podélný profil) je znázorněno na obr. 6 a posouzení shody je uvedeno v tabulce 4. Hodnota RMSE pro model $5 \mathrm{G}$ byla $1,50 \mathrm{~m}$. Hodnoty RMSE pro modelované sítě S1, S2 a S3 byly $0,44 \mathrm{~m}, 0,45 \mathrm{~m}$ a $0,44 \mathrm{~m}$. Hodnota MAE pro model $5 \mathrm{G}$ byla $1,47 \mathrm{~m}$ a pro modelované sítě S1, S2 a S3 0,34 m, 0,34 m a 0,35 m. Z výsledků je patrné, že modely S1, S2 a S3 vykazovaly srovnatelné chyby, které však byly výrazně nižší než chyby modelu 5G.

\section{Porovnání polohy hladiny}

Obrázek 7 popisuje odchylky v rozdílech WSE mezi srovnávanými DMT (5G, S1, S2, S3) a referenčními DMT. Výsledky ukazují, že nejhoršího výsledku bylo dosaženo modelem $5 \mathrm{G}$ a že variabilita $v$ rozdílech WSE se u tohoto modelu s rostoucím průtokem zvyšuje. Nejlepší mediánová hodnota a nejnižší variabilita u WSE byla poskytnuta modelem S3, který dosahuje nejlepších výsledků bez ohledu na modelovaný průtok. Posouzení velikosti chyb z porovnání vypočtené výšky hladiny je uvedeno $v$ tabulce 5 .

\section{Porovnání velikosti inundační oblasti}

Výsledky porovnání IA jsou uvedeny $v$ tabulce 6. Ve všech prípadech model významně nadhodnocuje rozsah IA. Pro průtoky $Q_{50}$ bylo toto nadhodnocení až o téměř $15 \%$. Zbylé modely výsledky mírně podhodnocovaly. Srovnatelných výsledků dosáhly modely S1 a S2, které podhodnocovaly s chybou menší než 5 \%. Nejlepších výsledků dosáhl model S3, jehož maximální chyba byla menší než $2 \%$.

\section{DISKUSE}

Prezentovaný postup pro matematický odhad říční batymetrie vyžaduje posouzení nejistot spojených s danými prístupy. Podobné posouzení vyžaduje i následná syntéza vypočtené říční batymetrie s daty TOPO a celková tvorba výsledného DMT určeného pro hydrodynamické modelování.

Výsledná přesnost při určení batymetrie je primárně závislá na přesnosti vstupních dat TOPO, která definují výškovou přesnost přilehlých inundačních území. Na území ČR jsou v současnosti standardně dostupná data TOPO získaná metodou LLS ve formě DMR 5G. Deklarovaná úpIná střední chyba těchto dat je 0,18 m pro vertikální přesnost $v$ otevřeném terénu a 0,30 m v zalesněném terénu [29]. Poloha hladiny určená pro zahloubení koryta toku zatížena touto chybou zanáší stejnou nejistotu i do přesnosti určení dna v korytě toku. Při použití jiných zdrojů vstupních dat, jako jsou například družicová data, se může tato nejistota lišit $v$ závislosti na použité technologii snímání zemského povrchu. Lze ale předpokládat, že s technologickým pokrokem bude docházet 


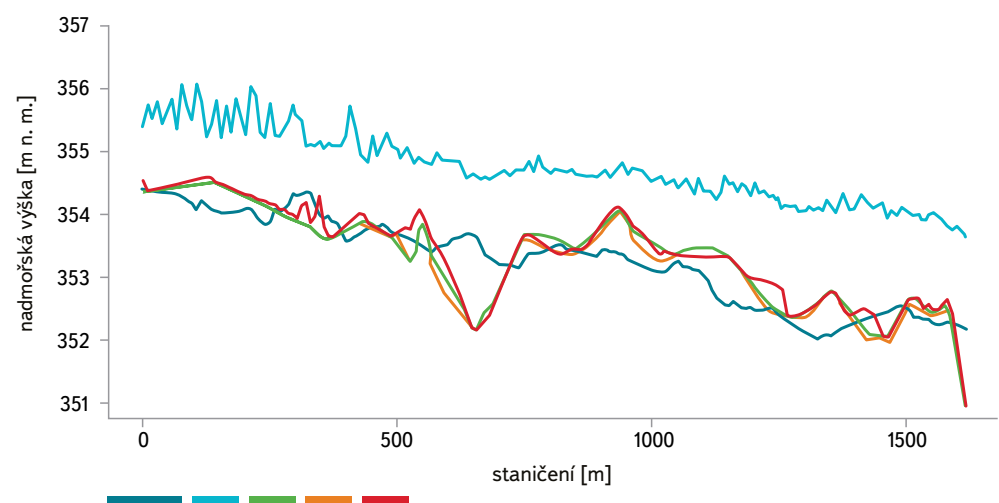

Obr. 6. Srovnání řezů v ose koryta

Fig. 6. Comparison of cuts in the channel axis

Tabulka 4. Hodnoty střednich kvadratických chyb (RMSE) a středních absolutnich chyb (MAE) pro porovnávané DMT (srovnání rezů v ose toku)

Table 4. Root mean square error (RMSE) and mean absolute error (MAE) values for the compared DEMs (channel axis comparison)

\begin{tabular}{lllll} 
& $\mathbf{5 G}$ & S1 & S2 & S3 \\
\hline RMSE $(\mathrm{m})$ & 1,50 & 0,44 & 0,45 & 0,44 \\
\hline $\operatorname{MAE}(\mathrm{m})$ & 1,47 & 0,34 & 0,34 & 0,35
\end{tabular}

ke zpřesňování metod pro snímání zemského povrchu a tím i k postupnému snižování této nejistoty. Nicméně data TOPO získaná metodou LLS jsou v současné době hojně využívána jako velmi přesný zdroj topografických dat pro hydrodynamické modelování [16-19, 26].

Na obr. 6 jsou vidět ve staničení cca 600 a cca 1600 dvě místa s výrazným odchýlením dna od reálného průběhu. Tyto odchylky mohou být způsobeny právě určením sklonu hladiny, který je vypočitáván z použitých dat TOPO. Určení špatného sklonu čáry energie má za následek nesprávný výpočet průtočné plochy daného profilu Chézyho rovnicí, tj. ustáleným rovnoměrným prouděním. Software pak nadměrně, nebo naopak nedostatečně zahloubí modelované koryto.

Koeficienty regresní rovnice jsou úzce spjaty s charakterem modelovaného toku. Pro uživatele jsou tyto koeficienty neznámé, a proto je nutné je odhadovat na základě podobnosti toků. Pro několik různých typů toků jsou v softwaru tyto regresní koeficienty i s fotodokumentací uvedeny. Nejistota v určení regresních koeficientů je předmětem navazujícího výzkumu.

Zjištění průtoků potřebných pro výpočet batymetrické sítě zajištuje prèdevším sít hydrografických stanic na významných vodních tocích. Pro určení průtoků u nepozorovaných vodních toků může být využito metody hydrologické analogie. Je otázkou, zda nepresnosti této metody u střední velikosti toků mohou výrazně ovlivnit výsledky hydrodynamického modelování, při kterém jsou modelované průtoky zpravidla vyšší i o několik rádů. Použití hydrologické analogie u malých vodních toků může zanášet již značnou chybu.

Volba metody schematizace říčního koryta může značně ovlivňovat celkovou kvalitu výsledků. Při nevhodném rozmístění virtuálních příčných profilů může docházet $k$ tomu, že modelované koryto může být, zejména $v$ říčních obloucích, vedeno príbřežní zónou namísto v prostoru reálného koryta. Tento prípad je znázorněn na obr. 4, část $B$. Jedná se o jev typický pro sítě SA1 a SA2 (obr. 2), což je dáno využitím lineární interpolace mezi jednotlivými profily. Tato zkreslení lze eliminovat zejména vhodným rozmístěním profilů a redukcí jejich vzdáleností.
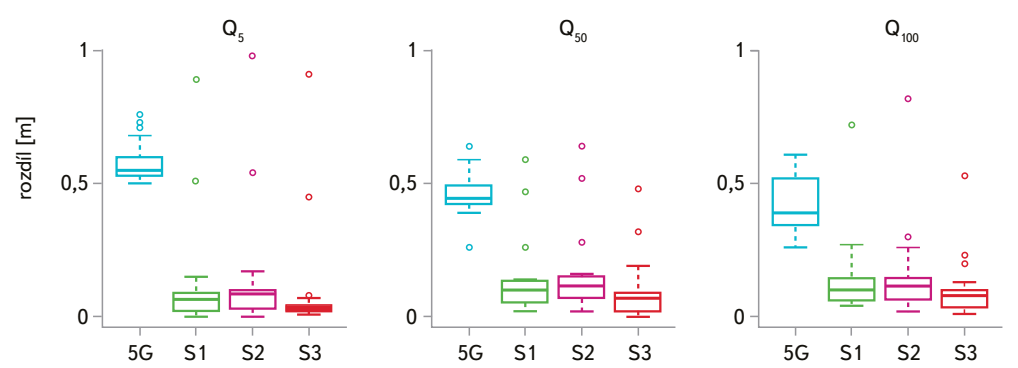

Obr. 7. Porovnání WSE v ose koryta

Fig. 7. Comparison of WSE in the channel axis

Tabulka 5. Chyby ve výšce hladin (WSE) při použití vybraných digitálnich modelů terénu (DMT) v porovnánís referenčním DMT pro vybrané N-leté prưtoky

Table 5. Water surface elevation (WSE) errors when usings elected digital elevation models (DEMs) compared to the reference DEM for the chosen $N$-year flow rates

\begin{tabular}{|c|c|c|c|c|}
\hline & & $\mathbf{Q}_{5}$ & $\mathbf{Q}_{50}$ & $\mathbf{Q}_{100}$ \\
\hline \multirow[t]{4}{*}{ RMSE (m) } & $5 G$ & 0,59 & 0,47 & 0,43 \\
\hline & S1 & 0,22 & 0,19 & 0,19 \\
\hline & S2 & 0,24 & 0,20 & 0,21 \\
\hline & S3 & 0,21 & 0,14 & 0,14 \\
\hline \multirow[t]{4}{*}{ MAE (m) } & $5 G$ & 0,58 & 0,47 & 3,42 \\
\hline & S1 & 0,11 & 0,13 & 0,13 \\
\hline & S2 & 0,12 & 0,15 & 0,14 \\
\hline & S3 & 0,09 & 0,09 & 0,09 \\
\hline
\end{tabular}

Tabulka 6. Plochy inundačních oblastí a jejich rozdilly od referenčníhodnoty vypočtené hydrodynamickým modelem pro vybrané N-leté průtoky

Table 6. Inundation areas and their differences from the reference value calculated by the hydrodynamic model for selected N-year flows

\begin{tabular}{lllll} 
& & $\mathbf{Q}_{\mathbf{5}}$ & $\mathbf{Q}_{\mathbf{5 0}}$ & $\mathbf{Q}_{\mathbf{1 0 0}}$ \\
\hline $\begin{array}{l}\text { Inundační oblast } \\
(\mathrm{IA}) \\
\left(\mathrm{km}^{2}\right)\end{array}$ & $\mathrm{ADCP}$ & 0,1129 & 1,1355 & 0,1544 \\
\cline { 2 - 5 } & $\mathrm{5G}$ & 0,1208 & 0,1556 & 0,1751 \\
\cline { 2 - 5 } & $\mathrm{S} 1$ & 0,1120 & 0,1293 & 0,1492 \\
\cline { 2 - 5 } & $\mathrm{S} 2$ & 0,1117 & 0,1293 & 0,1488 \\
\cline { 2 - 5 } & $\mathrm{S} 3$ & 0,1126 & 0,1335 & 0,1515 \\
\hline $\begin{array}{l}\text { Rozdíl v ploše } \\
\text { inundační oblasti } \\
(\%)\end{array}$ & $\mathrm{ADCP}$ & - & - & - \\
\cline { 2 - 5 } & $5 \mathrm{G}$ & 7,00 & 14,83 & 13,41 \\
\cline { 2 - 5 } & $\mathrm{S} 1$ & $-0,80$ & $-4,35$ & $-3,37$ \\
\cline { 2 - 5 } & $\mathrm{S} 2$ & $-1,06$ & $-4,58$ & $-3,63$ \\
\cline { 2 - 5 } & $\mathrm{S} 3$ & $-0,27$ & $-1,48$ & $-1,88$
\end{tabular}




\section{ZÁVĚR}

Cílem příspěvku je představení nových možností matematické schematizace reálného tvaru koryta vodního toku. Metoda je založena na matematickém odhadu reálného vzhledu príčných profilů a následném vytvoření batymetrické sítě celého říčního úseku. Metoda využívá při tvorbě celistvého DMT syntézy dat TOPO s hydrologickými daty (průtok a drsnost koryta $v$ době snímkování dat LLS).

Prezentované výsledky ukazují, že tvorba batymetrie koryta vodního toku pomocí softwaru Bathy_supp přináší nové možnosti a výrazné zjednodušení procesu prípravy DMT pro navazující hydrodynamické modelování.

Pro hodnocení nejistoty vstupních veličin softwaru Bathy_supp byly zpracovány citlivostní analýzy vlivu jednotlivých parametrů na spolehlivost určení tvaru a průtočné plochy modelovaných príčných profilů. Výsledky těchto analýz ukazují, že předložený prístup přináší výrazné zpřesnění výsledného modelu terénu použitého pro samotné hydrodynamické modelování povodňových scénárư. Zpracování rozsáhlé citlivostní analýzy bude předmětem navazující publikační činnosti.

Výhodou daného přístupu je jeho celosvětová aplikovatelnost. Přístup není omezen pouze na využití dat LLS jako vstupu, ale i ostatních dat dálkového snímání země. Díky tomu může být využit i v místech, kde probíhá pouze satelitní snímání povrchu. Jedinou podmínkou je dostatečná hustota topografických bodových dat pro model Bathy_supp.

Autoři si uvědomují, že přesnost popsaného způsobu tvorby říční batymetrie má svá omezení. Hlavním omezením je nejistota v určení výšky hladiny a jejího sklonu ve virtuálních prričných profilech. Ta je závislá na deklarované přesnosti dat LLS. Stejnou nejistotou je zatižen i parametr sklonu pro Chézyho rovnici. Lze ale předpokládat, že s technologickým rozvojem metod pro snímání zemského povrchu bude docházet ke snižování této chyby.

\section{Poděkování}

Tento př́spěvek vznikl za podpory Technologické agentury ČR, projektu Číslo TJ01000132 Pokročilé zpracování dat leteckého laserového skenování za účelem schematizace vodnich toků pro potreby matematického modelování.

\section{Literatura}

[1] MERWADE, V., OLIVERA, F., ARABI, M., and EDLEMAN, S. Uncertainty in Flood Inundation Mapping: Current Issues and Future Directions. Journal of hydrologic Engineering, 2008, vol. 13, No. 7, p. 608-620.

[2] UHLÍŘOVÁ, K. a ZBOŘIL, A. Možnosti využití Laserového snímání povrchu pro vodohospodářské účely. Vodni hospodárství, 2009, roč. 59, č. 12, s. 11-15.

[3] PAVLÍČKOVÁ, L., NOVÁK, P., ROUB, R. a HEJDUK, T. Využití geografických informačních systémů a územně plánovací dokumentace při modelování povodňového rizika. Vodohospodářské technickoekonomické informace, 2012, roč. 54, č. 4, s. 1-6, príloha Vodního hospodářství č. 8/2012.

[4] BALTSAVIAS, E.P. Airborne laser scanning: basic relations and formulas. ISPRS Journal of Photogrammetry and Remote Sensing, 1999, vol. 54, No. 2-3, p. 199-214.

[5] CASAS, A., BENITO, G., THORNDYCRAFT, V.R., and RICO, M. The topographic data source of digital terrain models as a key element in the accuracy of hydraulic flood modelling. Earth Surface Processes and Landforms, 2006, vol. 31, No. 4, p. 444-456.

[6] HILLDALE, R.C. and RAFF, D. Assessing the ability of airborne LiDAR to map river bathymetry. Earth Surface Processes and Landforms, 2008, vol. 33, p. 773-783.

[7] CAVALLI, M. and TAROLLI, P. Application of LiDAR technology for river analysis. Italian Journal of Engineering Geology and Environment, 2011, Special Issue I, p. 33-44.

[8] GUENTHER, G.C., CUNNINGHAM, A.G., LAROQUE, P.E., and REID, D.J. Meeting the accuracy challenge in airborne Lidar bathymetry. Proceedings, 20th EARSeL Symposium Workshop on LiDAR Remote Sensingof Land and Sea. Dresden, Germany, June 16-17, 2000, 28 p.

[9] SKINNER, K.D. Evaluation of LiDAR-Acquired Bathymetric and Topographic Data Accuracy in Various Hydrogeomorphic Settings in the Lower Boise River, Southwestern Idaho, 2007. Scientific Investigations Report 2009 - 5260. US Geological Survey. 20 p.
[10] BAILLY, J.S., COARER, Y., LANGUILLE, P., STIGERMARK, C.J., and ALLOUIS, T. Geostatistical estimations of Bathymetric LiDAR errors on rivers. Earth Surface Processes and Landforms, 2010, vol. 35, No. 10, p. 1199-1210.

[11] NOVÁK, P., ROUB, R., VYBÍRAL, T., MARVAL, S., HEJDUK, T. a BUREŠ, L. Letecké batymetrické laserové skenování. Geodetický a kartografický obzor, 2017, roč. 6 3/105, č. 10, s. 197-209.

[12] MERWADE, V., COOK, A., and COONROD, J. GIS techniques for creating river terrain models for hydrodynamic modeling and inundation mapping. Environmental modelling and Software, 2008 vol. 23, No. 10-11, p. 1300-1311.

[13] NOVÁK, P., ROUB, R., VYBÍRAL, T., HLAVÁČEK, J., HEJDUK, T., BUREŠ, L. a REIL, A. Nové technologie batymetrie vodních toků a nádrží. Vodní hospodářství, 2015, 65, s. $13-20$.

[14] CALETKA, M., Možnosti extrapolace digitálního modelu terénu z rastru DMR 5G. Vodohospodárské technicko-ekonomické informace, 2017, 5, s. 18-23.

[15] ROUB, R., HEJDUK, T., and NOVÁK, P., Automating the Creation of Channel Cross Section Data from Aerial Laser Scanning and Hydrological Surveyingfor Modeling Flood Events. J. Hydrol. Hydromech 2012, vol. 60, No. 4, p. 227-241.

[16] ROUB, R., URBAN, F., HAVLÍ̌̌EK, V., NOVÁK, P., HEJDUK, T., BUREŠ, L. a REIL, A. Vývoj softwarových nástrojů CroSolver a CroSolver for ArcGIS pro prípravu výpočetní tratě hydrodynamických modelů. Vodohospodárské technicko-ekonomické informace, 2015, roč. 57, č. 1, s. 5-13.

[17] VETTER, M., HÖFLE, B., MANDELBURGER, G., and RUTZINGER, M. Estimating changes of riverine landscapes and riverbeds by using airborne LiDAR data and river cross-sections. Zeitschrift für Geomorphologie, Supplementary Issues, 2011, 55.2, p. 51-65.

[18] CHEN, W. and LIU, W., Modeling the influence of river cross-section data on a riverstage using a two-dimensional/three-dimensional hydrodynamic model. Water, 2017, 9.3, p. 203.

[19] CAVIEDES-VOULLIĖME, D., MORALES-HERNÁNDEZ, M., LÓPEZ-MARIJUAN, I., GARCÍA-NAVARRO $P$. Reconstruction of $2 D$ riverbeds by appropriate interpolation of $1 D$ cross-sectional information for flood simulation. Environmental modelling \& software, 2014, 61, p. 206-228.

[20] BRÁZDIL, K. Projekt tvorby nového výškopisu území České republiky. Geodetický a kartografický obzor, 2009, 55.97, s. 145-151.

[21] BRUNNER, G.W. HEC-RAS river analysis system: hydraulic reference manual. US Army Corpsof Engineers, Institute for Water Resources, Hydrologic Engineering Center, 2010.

[22] WERNER, M.G.F., A comparison of flood extent modelling approaches through constraining uncertainties on gauge data. Hydrology and earth systems ciences, 2004, 8.6, p. 1141-1152.

[23] SCHUMANN, G., MATGEN, P., CUTLER, M.E.J., BLACK, A., HOFFMANN, L., and PFISTER, L. Comparison of remotely sensed waterstages from LiDAR, topographic contours and SRTM. ISPRS Journal of Photogrammetry and Remote Sensing, 2008, 63.3, p. 283-296.

[24] YAN, K., DI BALDASSARRE, G., and SOLOMATINE, D.P. Exploring the potential of SRTM topographic data for flood inundation modelling under uncertainty. Journal of Hydroinformatics, 2013, 15.3, p. 849-861.

[25] COOK, A. and MERWADE, V. Effect of topographic data, geometric configuration and modeling approach on flood inundation mapping. Journal of Hydrology, 2009, 377.1-2, p. 131-142.

[26] ROUB, R., KURKOVÁ, M., HEJDUK, T., NOVÁK, P., and BUREŠ, L. Comparing a hydrodynamic mode from fifth generation DTM data and a model from data modified by means of CroSolver tool. AUC Geographica, 2016, 51.1, p. 29-39.

[27] ACKERMAN, C.T. HEC-GeoRAS; GIS Toolsfor support of HEC-RAS using ArcGIS. United States Army Corpsof Engineers, Davis, 2005.

[28] HORRITT, M.S. and BATES, P.D. Evaluation of $1 D$ and 2D numerical models for predicting river flood inundation. Journal of hydrology, 2002, 268.1-4, p. 87-99.

[29] BRÁZDIL, K. Technická zpráva k digitálnímu modelu reliéfu 5. generace (DMR 5G). Zeměměřický úřad, Vojenský geografický a hydrometeorologický úřad, 2012 
Autoři

Ing. Luděk Bureš ${ }^{1}$

凶buresl@fzp.czu.cz

Ing. Petra Sychová, Ph.D.'

凶sychova@fzp.czu.cz

Ing. Lenka Pavlíčková1

凶pavlickova@fzp.czu.cz

Ing. Štěpán Marval²

凶marval.stepan@vumop.cz

Ing. Filip Urban ${ }^{3}$

凶urban@vrv.cz

Ing. Radek Roub, Ph.D.

四roub@fzp.czu.cz

'Česká zemědělská univerzita v Praze, Fakulta životního prostředí

${ }^{2}$ Výzkumný ústav meliorací a ochrany půdy, v. v. i.

${ }^{3}$ Vodohospodářský rozvoj a výstavba, a. s.

Příspěvek prošel lektorským řízením.

\section{MATHEMATICAL ESTIMATION OF WATERCOURSE BATHYMETRY - BATHY_SUPP SOFTWARE \\ BURES, L.'; SYCHOVA, P.'; PAVLICKOVA, L.'; MARVAL, S. ${ }^{2}$; URBAN, F. $^{3}$; ROUB, R. ${ }^{1}$}

${ }^{1}$ Czech University of Life Sciences Prague, Faculty of Environmental Sciences

${ }^{2}$ Research Institute for Soil and Water Conservation

${ }^{3}$ Water Management Development and Construction

Keywords: airborne laser scanning - hydrodynamic model bathymetry - river channels - digital elevation model - floods

Topographic data play an important role in the hydrodynamic modelling of flood events. An accurate and precise digital elevation model (DEM) with a bathymetric description of the river channel is often required. DEMs can be derived from various data sources, e.g. ground surveying or remote sensing techniques. It is often costly and time-consuming to perform ground surveys, and especially to obtain geodetic data. Source data for DEM can also be obtained from satellites; however, these DEMs are insufficiently accurate for precise hydrodynamic modelling. Aerial laser scanning (ALS) appears to be the most appropriate method for obtaining relevant source data.

An infrared laser beam is widely used in the Czech Republic for collecting ALS data. A limitation on the use of this technology for the purposes of hydrodynamic modelling is that an infrared laser beam is absorbed by water. In practice, this means that there is a lack of precise and complete information on the topography of the streambed below the water level of the stream. A DEM created from ALS data results in a model that neglects the flow areas of the river channel.

Our study presents results from the development of the Bathy_supp software tool, which determines the bathymetry of natural river channels. The bathymetry is determined with the use of analytical curves describing the course of cross-sections. Subsequently, spatial interpolation among the estimated cross-sections is made, resulting in bathymetric point network. This bathymetric point network can be combined, for example, with ALS data to create a DEM suitable for hydrodynamic modelling. This paper presents a practical example of software tests on a study area. Bathy_supp software provides significantly better results than a terrain model created from ALS data. 